DOI: $10.2478 / \mathrm{v} 10025-009-0005-\mathrm{x}$

JOURNAL OF WATER

AND LAND DEVELOPMENT

J. Water Land Dev. No. 12, 2008: 49-58

\title{
Impact of a road crossing on groundwater level in a river valley
}

\section{Waldemar MIODUSZEWSKI}

Institute for Land Reclamation and Grassland Farming, Falenty, 05-090 Raszyn, Poland, e-mail: w.mioduszewski@imuz.edu.pl

\begin{abstract}
Many of already existing roads cross wetland river valleys. Also the roads nowadays planned are cutting through valuable wetlands. It is necessary to evaluate the range of their impact on the natural environment. This paper focuses only on the analysis of the road crossing impact on the groundwater level. Two options of crossing the wetlands were analyzed, building the road on embankments and in the bridge. It was assumed that the valley is filled with organic material under laid by permeable sands. Calculation results showed that building a road in the valley affects groundwater level only to the slight extend. Water conditions in the valley may be affected only during the construction of the road. Calculation results were confirmed by field observations.

It should be stressed that the object of this paper is the evaluation of water conditions. Environment might be influenced by other factors.
\end{abstract}

Key words: groundwater, nature protection, river valleys, roads

\section{INTRODUCTION}

Transportation routes cross in many cases river valleys. Usually over the river a bridge is built and in the valley, the road is constructed on the embankment. Partition of the river valley may cause unfavorable changes in the environment, especially vulnerable are hydrogenic habitats. There are some very wide river valleys which are protected (National Parks, the area of Natura 2000 etc.), and in the same time there are plans to construct roads crossing these valleys (GÓRNIAK, WIATER, 2007). It is high probability that the road can have a negative impact on the flora and fauna of such valley. In that paper some studies have been presented to explain the influence of the road on ground water level only.

The high nature value of river valleys, the occurrence of peat deposits, varied wetland flora and fauna is the result of specific water conditions. It is suspected that some human interference might result in disturbance of natural conditions of river valleys. The construction might have negative influence on many environ- 
mental factors, i.e. air, soil, water, land surface, etc. Degradation of hydrogenic sites may occur as a result of change of water conditions (OKRUSZKO et al., 2007). As a consequence of high waters and spring floods in the valley, characteristic for this conditions diversity of hydrogenic habitats arouse. Changes of surface and ground water levels might affect considerably the local flora and fauna and cause the disturbance of ecological balance. For this reason, the prediction of effects of measures undertaken is always essential (MIODUSZEWSKI, 2007).

The object of the study was the evaluation of the impact of road construction on the groundwater table in the river valley during its construction and operation. Other possible environmental effects of the structure were not subject of this study.

\section{ASSUMPTIONS AND PROPOSED CONSTRUCTION SOLUTIONS}

Different solutions of construction and building technology of the road crossing the river valley were analyzed. The most probable, from the environmental and economical point of view, is implementation of one of the following scenarios (Fig. 1):

- A - a road cross the river valley on an estacade (a bridge) built on its entire length of the valley;

- B - building an estacade (overpass with the bridge) over the river and part of the valley, accompanied by an embankment on the remaining part of the valley (Fig. 1).
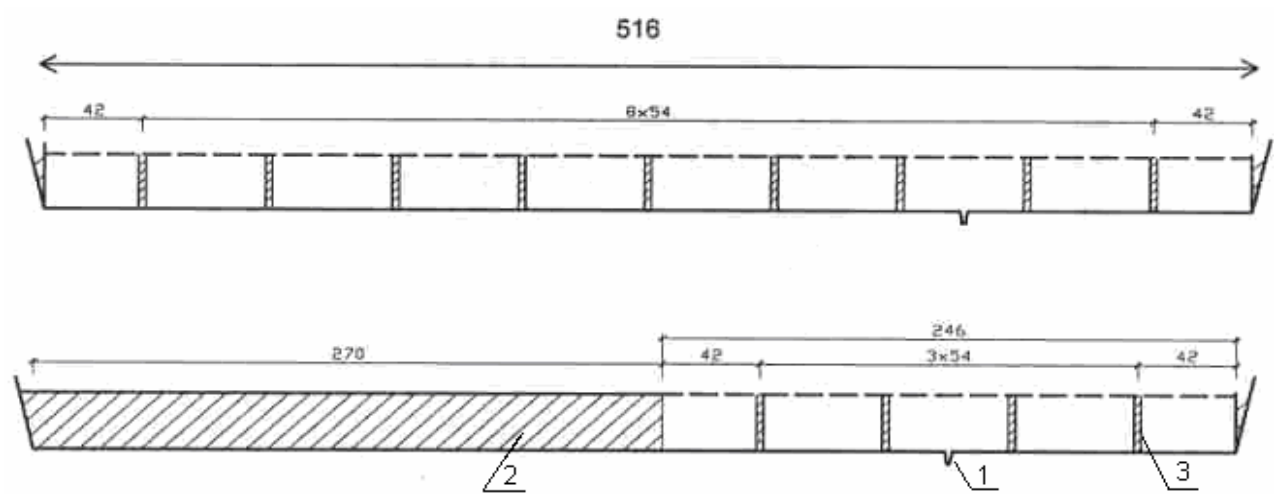

Fig. 1. A scheme of road crossing the river valley; 1 - river, 2 - embankment, 3 - piers (estacade) 


\section{RESEARCH AREA CHARACTERISTICS}

A small river was chosen with wide valley (approximately $0.5 \mathrm{~km}$ ) covered by organic soil. The valley is rather flat and the longitudinal gradient of the river is less than $0.1 \%$. That area has a very high natural value (SOKOŁOWSKI, 1991). Therefore it is imported to keep the water condition unchanged.

For the modeling purpose, a part of the river valley of $2.5 \mathrm{~km}$ was selected together with a part of the adjacent high plain (Fig. 2). For this area, a scheme of geological structure together with its hydrogeological conditions was elaborated, which was indispensable for the modeling.

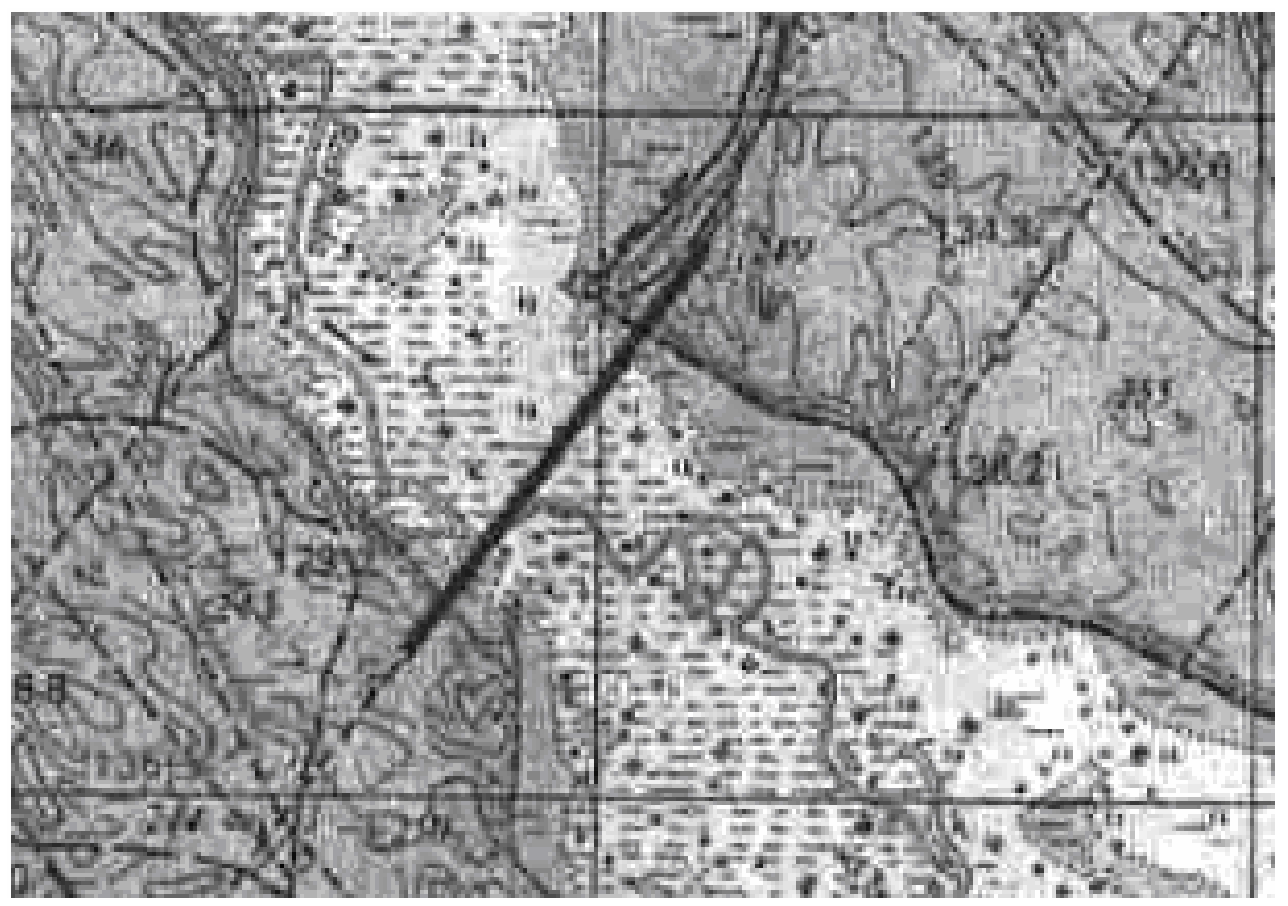

Fig. 2. Map of the river valley chosen for the study

Scheme of geological structure of the valley and part of the adjacent high plain was elaborated on the basis of the archive data, geological maps and also a field recognition (Fig. 3a, b). The analyzed area is composed of peat, mainly of sedge and reed origin, of a thickness up to $5 \mathrm{~m}$. Groundwater table in the valley is just under the land surface. The depth of groundwater table in the high plain was estimated on the basis of hydrogeological maps and a field recognition-depth of groundwater table in existing wells (Fig. 3a). 
a)

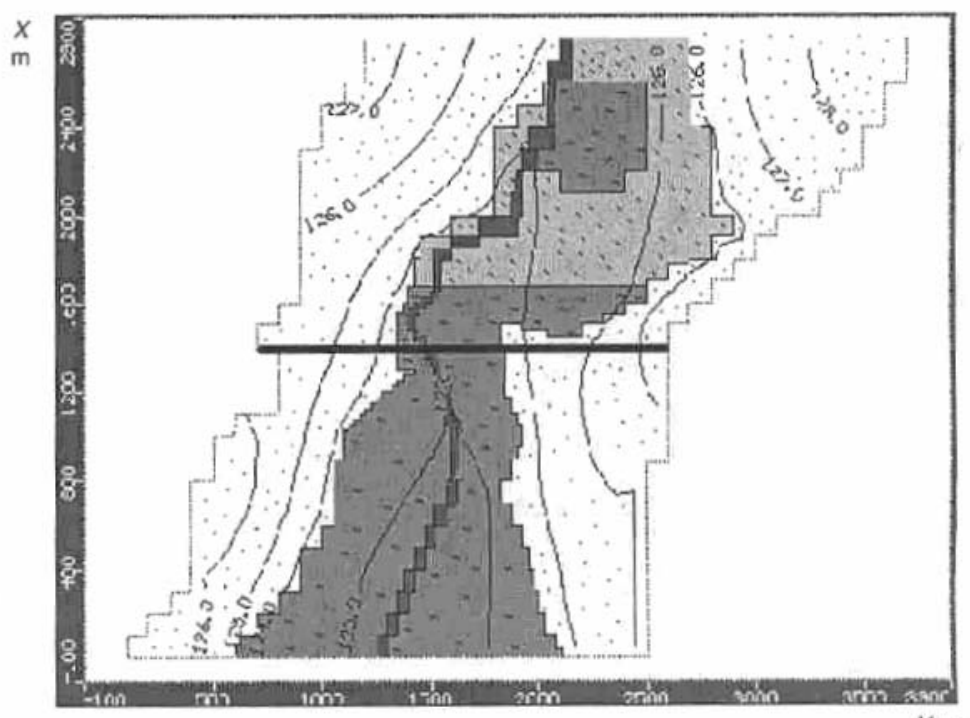

b)

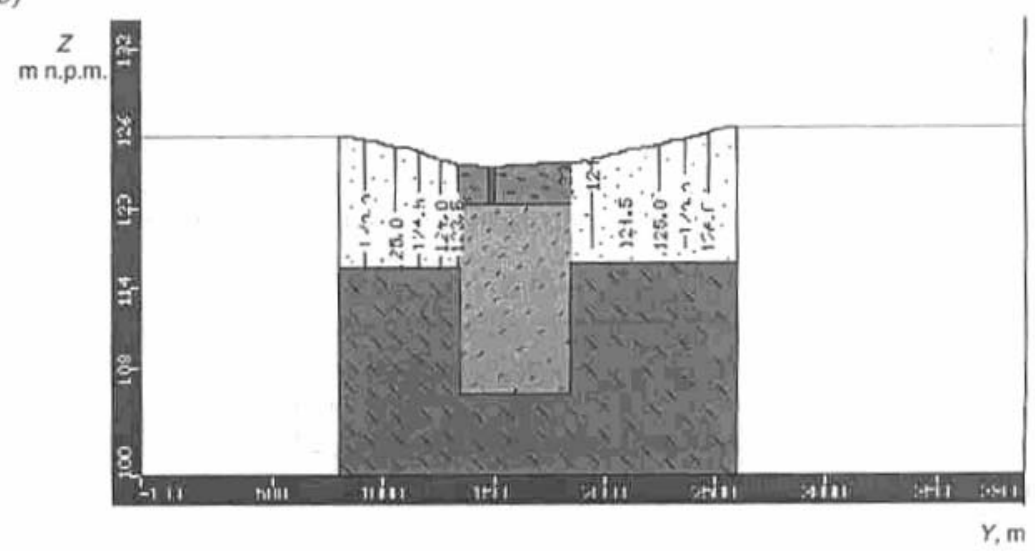

-.-126,0-..- groundwater level

sand, $k=4 \mathrm{~m}^{-1}$

sand, $k=12 \mathrm{~m} \cdot \mathrm{d}^{-1}$

peat, $k=1,5 \mathrm{~m} \cdot \mathrm{d}^{-1}$

peat, $k=2{\mathrm{~m} \cdot \mathrm{d}^{-1}}^{-1}$

clay, $k=0,01 \mathrm{~m} \cdot \mathrm{d}^{-1}$

$\square$ river

Fig. 3. The river valley; a) plan, b) cross section A - A as shown in Fig 3a

\section{CALCULATIONS OF GROUNDWATER TABLE}

Modeling studies were conducted with the use of 3-dimentional numerical model MODFLOW in the version 1.5. The program is used to simulate groundwater flow in the saturation zone under steady state conditions. The model area is 
a rectangle of $4000 \mathrm{~m}$ by $3000 \mathrm{~m}$ (Fig. 3a). The basic net was created by squares of $100 \mathrm{~m}$. In the road area, the squares were smaller: 50 and $25 \mathrm{~m}$.

Calculations were conducted for the following scenarios.

Scenario 0: On the basis of actual data the scenario " 0 " was created, so-called "initial" one. It reflects existing conditions. Assuming fixed marginal conditions, groundwater table location was calculated (hydro isolines) in the valley and on the high plain area. It appears that a measured and calculated groundwater table was about equal at the valley edge. It was assumed that the used model in the precise way reflects the water conditions in the area. This scenario was used as a base scenario to compare with the other scenarios, in order to estimate their impact on the groundwater table in the valley.

The impact of road crossing on groundwater level was calculated for two examples of road construction. For both scenarios 3 different variants were considered to represent the situation during construction and after completion of the valley crossings. For all scenarios the dynamics of groundwater table was considered.

Scenario A - a long estacade (bridge).

A-1 (operation scenario) - it is assumed that in the permeable and organic layer pylons will be introduced. Impermeable poles / pylons / of the size $5 \times 5 \mathrm{~m}$ (bridge pier, pile, soil) and depth of $20 \mathrm{~m}$ will be constructed (Fig. 1).

A-2 (under construction scenario) - it is assumed that in order to enable the installation of piers, dewatering of the fundamental pits will be conducted. Groundwater table in the area bordered by the impermeable screen will be lower by $1.5 \mathrm{~m}$ below the ground level. In this scenario, simultaneous dewatering of excavation with the use of pump installed in ten points of planned localization of piers is proposed. The implementation of this scenario is very unlikely. It is not necessary to dewater all pits at the same time. Calculations for this scenario were conducted in purpose to present radical (extreme) solutions and their impact on water conditions.

A-3 (under construction scenario) - it is assumed that the groundwater table will be lowered by $1.5 \mathrm{~m}$ below the ground level, but the pumping will be performed at one point at a time only. After the pier is built, pumping in the next point starts.

Scenario B - a short estacade (short bridge) with an embankment (Fig. 1).

B-1 - it is assumed that the embankment will be built from permeable material (ie. fine sands) of the hydraulic conductivity $k=40 \mathrm{~m} \cdot \mathrm{day}^{-1}$. Under the embankment, settlement of an organic layer will happen with the simultaneous ground displacement. However, a thin, low-permeable layer of thickened organic material will remain with the permeability coefficient $k=0.01 \mathrm{~m} \cdot \mathrm{day}^{-1}$.

B-2 - it is assumed that under the embankment settlement of the mineral layer below the peat deposit will have place (only within the valley). In the mineral layer below the embankment, vertical screen of sand soil with lower hydraulic conduc- 
tivity $k$ will form. It is supposed that natural permeability, $k=12 \mathrm{~m} \cdot \mathrm{day}^{-1}$, will be lowered to $k=6 \mathrm{~m} \cdot \mathrm{day}^{-1}$. Between the soil bank and mineral layer, consolidated layer of peat $k=0.01 \mathrm{~m} \cdot \mathrm{day}^{-1}$ will form, as in the scenario B-1.

B-3 - it is assumed that the embankment will be constructed from a lowpermeable material (i.e. clay, silt, of permeability coefficient $k=0.01 \mathrm{~m} \cdot \mathrm{day}^{-1}$ ). Also, permeability of the mineral layer underlying peat deposit will be changed within the valley as in the scenario B-2, and the hydraulic conductivity will be lowered to $k=6 \mathrm{~m} \cdot \mathrm{day}^{-1}$. This scenario presents a unique situation, when the soil bank is of clay and silt. According to building rules, low-permeable materials ought not to be placed on the organic layers.

\section{ANALYSIS OF THE CALCULATION RESULTS}

Three numerical calculations were conducted respectively for the scenario A (long estacade) and B (short estacade with an embankment) of planned road crossing the river valley.

In the scenario A - the groundwater table on the upstream and downstream of the estacade is on the same level. The disturbance of the natural level and significant lowering of groundwater table occurs only during the dewatering of the piers' pits. During simultaneous dewatering of all fundamental pits (scenario A-2) the lowering of the groundwater table ranges across the whole valley (Fig. 4a). If the
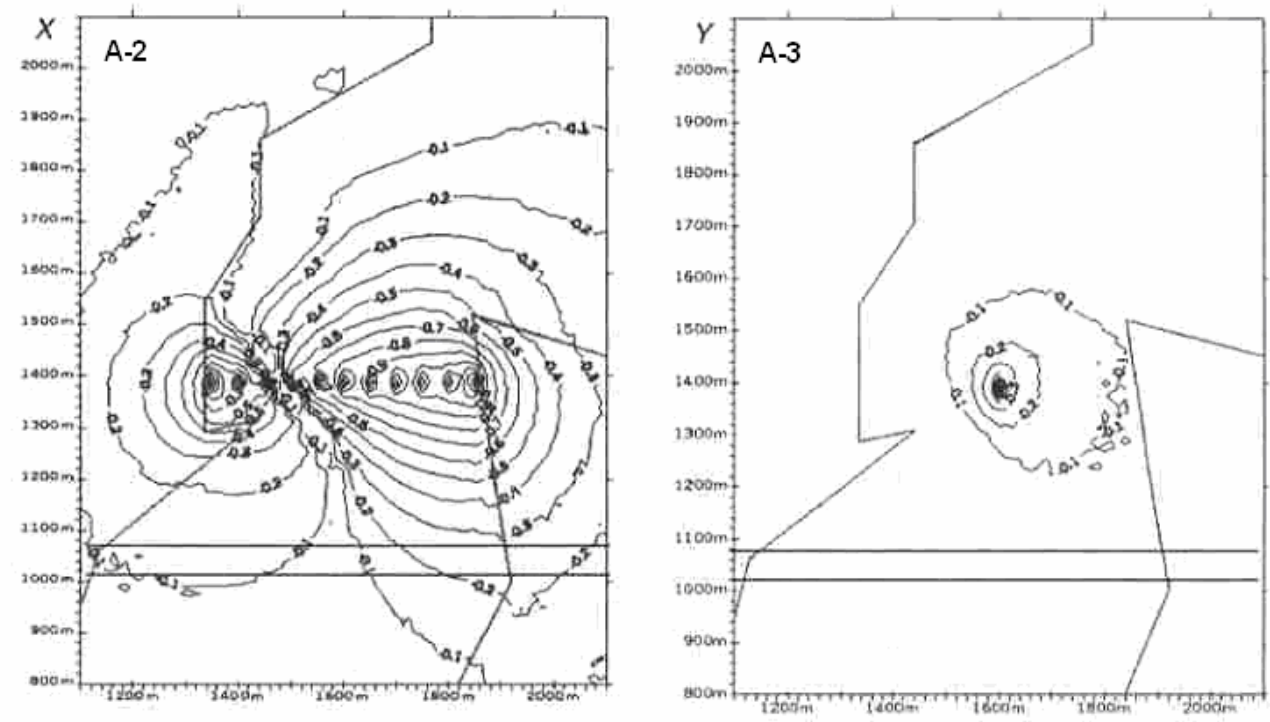

Fig. 4. Changes of groundwater tables in the valley: scenario A-2 and A-3; isolines at every $0.1 \mathrm{~m}$ 
water is pumped only from one pit at a time (scenario B-3), decrease of groundwater table is comparably deep but occurs on the smaller area (Fig. 4b).

Building the embankment with a short estacade has far less impact on the groundwater table (Fig. 5). Even building the embankment of the low permeable soil will not induce relevant changes in groundwater flow.
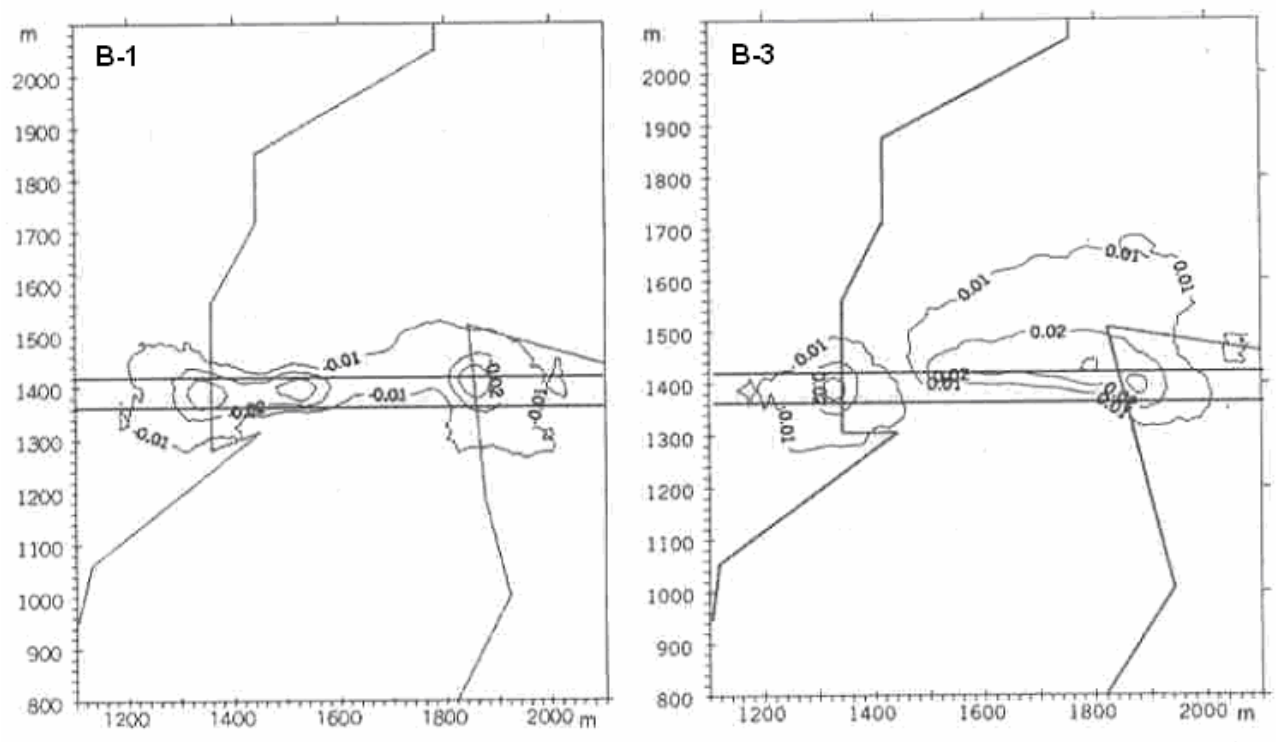

Fig. 5. Changes of groundwater tables in the valley: scenario B-1 and B-3; isolines every $0.01 \mathrm{~m}$

In both analyzed scenarios - A (long estacade) and B (short estacade), the fluctuations of groundwater table triggered by building the road are very small and close to the modeling error. The installation of piers and building of embankments will not disturb the groundwater flow during the operation of the facility. The cross section of the piers placed in the ground is very small compared to the whole valley with the high plain cross section and so, in the case of laminar flow of groundwater, this slight reduction of the flow area will not cause disturbance of the groundwater flow.

Assumed for calculation purposes, decrease of permeability of the mineral layer and forming a thin peat deposit layer with low permeability under the soil bank causes only slight disturbance for the groundwater flow. It follows the fact that consolidated peat layer is of small thickness in comparison with the aquifer thickness and permeability of underlying mineral layer is only slightly decreased and limited to the ground of low volume compared with the whole modeled area. It is worth noting that both forming the consolidated peat deposit and change of per- 
meability of the mineral layer is assumed only in the valley area, whereas ground waters flow also in the adjacent high plain, composed of permeable material.

\section{FIELD OBSERVATIONS}

In Poland many road and rail crossings were built cutting through wetland river valleys. Mainly these are bridges over the valley and soil embankments in the valley. However their impact on ground waters and water conditions were not analyzed.

In the figure 6 road embankment crossing wide wetland river valley built before the First World War were presented. In the ground the shallow peat layer is under laid by permeable material (Fig. 7) [MIODUSZEWSKI et al., 1978]. Observa-

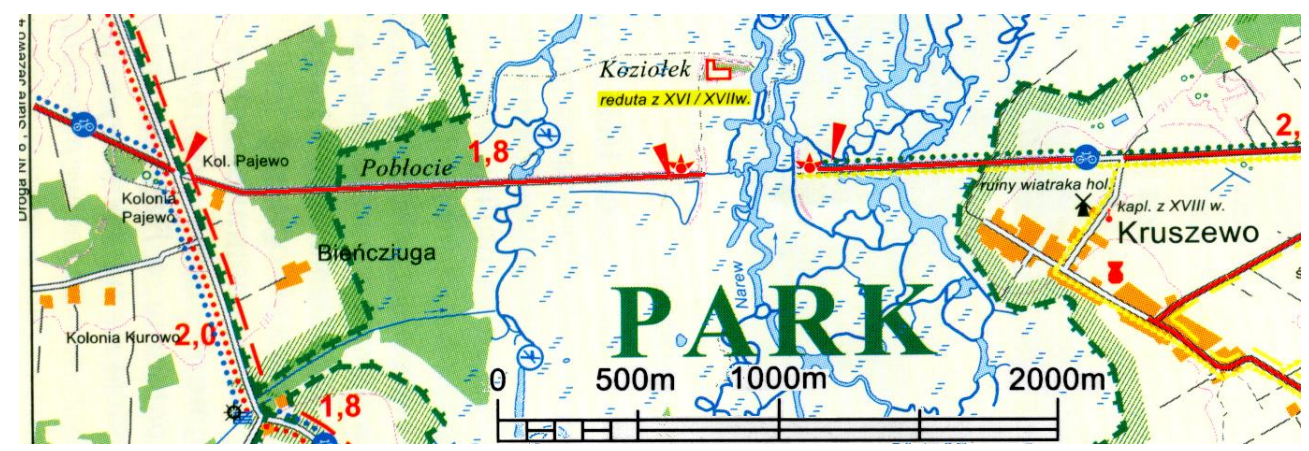

Fig. 6. The old embankment in the river valley
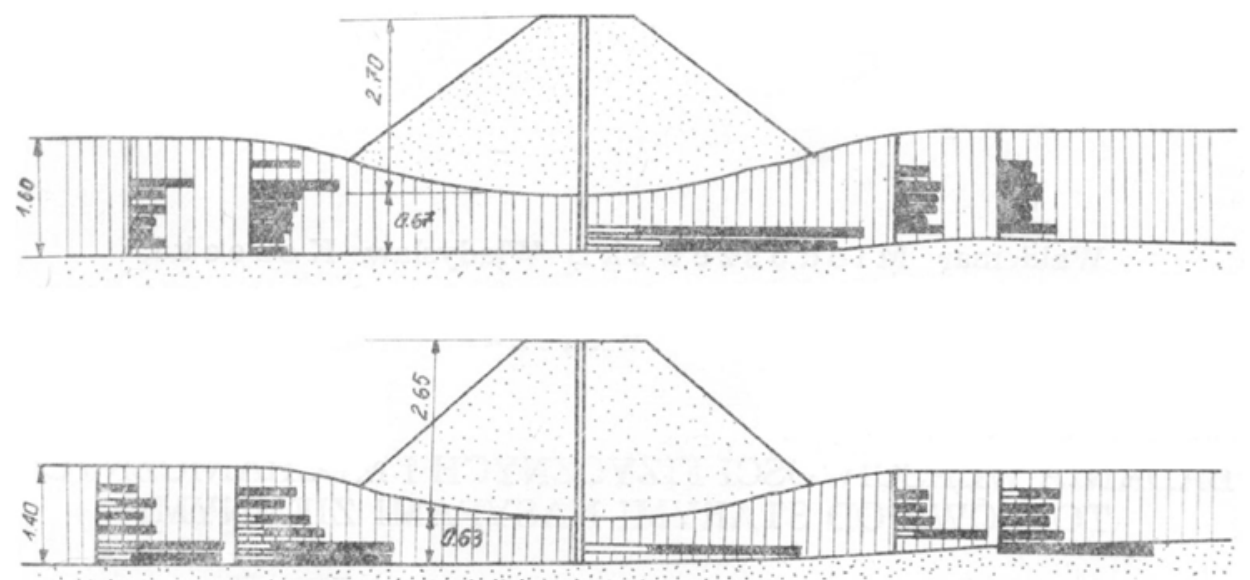

Fig. 7. The examples of cross-section of the road embankment crossing the river valley. The results of shear strength measurement 
tions showed that the groundwater is on the same level on both sides of the embankment. Plant cover is also similar on both sides. The fact that this area is proposed to be a nature reserve confirms its high natural value [Plan ochrony..., 2001].

\section{CONCLUSIONS}

On the basis of conducted modeling research of impact of road crossing the river valley on groundwater and some field observations the following conclusions arise:

- The implementation of the road construction presented in the scenarios A (a bridge - long estacade) and B (short bridge with a earth embankment) should not induce significant changes in groundwater level in the river valley. On the basis of the modeling results it may be stated that the groundwater table fluctuations are insignificant.

- From the point of view of the road impact on the water environment of river valley, both scenarios (A and B) are comparable and their influence on groundwater is not relevant.

- The observations of a few road crossing the wide swampy valleys show that the impact of the embankment on groundwater level and hydrological condition in valley is insignificant.

Conducted modeling researches were limited only to the impact of the constructed road crossing the river valley on the groundwater flow. It did not concern other environmental effects, which may be induced by the building of a road. According to achieved results, analyzed scenarios will not cause relevant changes in groundwater dynamics. However, it should be stressed that the fact that the analyzed scenarios will not bring changes in groundwater flow, does not mean that other environmental factors remain unchanged.

\section{REFERENCES}

1. GóRniaK A., Wiater J., 2007. Obecna i planowana sieć dróg kołowych i obwodnic, ich kolizyjność ze środowiskiem na przykładzie Podlasia. (Present and future road net and town rings, their environmental collision on the example of Podlasie voievodship). In: Problemy naukowo-badawcze budownictwa. T. 1. Problemy budownictwa na terenach ekologicznie cennych. Białystok, Wydaw. PBiał.

2. MioduszewsKi W., 2007. Wpływ budowli hydrotechnicznych na środowisko i problemy renaturyzacji siedlisk zdegradowanych na przykładzie doliny Biebrzy i Narwi. (Impact of hydraulic structures on environment and some problems on revitalization of degraded ecosystems (on the examples of Biebrza and Narew valleys). In: Problemy naukowo-badawcze budownictwa. T. 1. Problemy budownictwa na terenach ekologicznie cennych. Białystok, Wydaw. PBiał. 
3. Mioduszewski W., Kosecki W., WALCZAK H., 1978. Badania właściwości fizycznych i mechanicznych torfów pod starymi nasypami ziemnymi. (Investigation of physical and mechanical properties of peat under old embankments). Wiad. IMUZ t. 14 z. 1.

4. Okruszko T., Maltby E., SzatyŁowicz J., Świątek P., Kotowski W., 2007. Wetlands: monitoring, modelling and management. Wydaw. Taylor \& Francis / Balkema.

5. Plan ochrony Narwiańskiego Parku Narodowego, 2001. (The management protection plan of Narew National Park). Manuscript.

6. SoKOŁOWSKi A., 1991. Przyrodnicze obiekty chronione województwa białostockiego. (Natural areas protected in the Białystok voievodship). Białystok, Wydaw. Woj. Konserwator Przyrody.

\section{STRESZCZENIE}

\section{Wpływ przejścia drogowego na poziom wód gruntowych w dolinie rzecznej}

Słowa kluczowe: doliny rzeczne, drogi, ochrona środowiska, wody gruntowe

Wiele istniejących dróg przecina zabagnione doliny rzeczne. Również obecnie planowane są nowe trasy drogowe, prowadzące niekiedy przez cenne przyrodniczo obszary bagienne. Niezbędna jest więc ocena, w jakim stopniu te inwestycje oddziaływają negatywnie na środowisko przyrodnicze. W niniejszej pracy skoncentrowano się jedynie na analizie wpływu przejścia drogowego na poziom wód gruntowych. Rozpatrywane były drogi budowane na nasypie oraz w postaci estakady wykonanej na palach wbitych w podłoże gruntowe. Przyjęto założenie, że dolina zbudowana jest $\mathrm{z}$ utworów organicznych podścielonych przepuszczalnymi utworami piaszczystymi. Wyniki obliczeń wykazują, że budowa drogi przez dolinę w niewielkim stopniu wpływa na poziom wód gruntowych. Pewne zakłócenia stosunków wodnych mogą wystapić jedynie w trakcie budowy. Wyniki obliczeń potwierdzają obserwacje terenowe.

Zwraca się uwagę, że praca dotyczy tylko i wyłącznie oceny warunków wodnych. Na stan środowiska mogą mieć wpływ również inne czynniki.

Reviewers:

Prof. Erik Querner

Dr Wladimir Bleuten 